\title{
HUBUNGAN KEKERABATAN FENETIK VARIETAS PISANG (Musa sp.) DI PULAU AMBON
}

\author{
Rahmayani Notanubun ${ }^{1}$, Ritha L. Karuwal ${ }^{2}$ \\ ${ }^{1}$ Alumni Program Studi Pendidikan Biologi \\ ${ }^{2}$ Program Studi Pendidikan Biologi
}

E-mail: rithakaruwal@yahoo.com

\begin{abstract}
Background: Banana is a tropical fruit that has been popular in the community, and potentially developed in Indonesia. There are many varieties of bananas that grow wild or cultivated by the community. This leads to differences in characters between each type. The differences can be seen from the appearance of plants such as pseudo-stems, leaves, flowers, and fruit. The difference is important to know the relationship of kinship between species so that can be obtained initial information in improving the genetic properties that will produce plants with new varieties are superior.

Methods: This study was conducted from December 2012 to May 2013 with the research site of Ambon Island and used exploratory methods based on the banana descriptor guidelines from the International Plant Genetic Resources Institute (IPGRI, 1996).

Results: The study showed that 7 varieties were found and identified: forty-day bananas, Jawaka, Kepok, Ambon green, King, Gold and Horn with varying morphological appearance and formed 2 main clusters with close and distant kinship.

Conclusion: Banana on the island of Ambon has the characterization so that many sources of potential diversity need to be revealed more.
\end{abstract}

Keywords: kinship relationship, Fenetik, Banana, Ambon Island

\begin{abstract}
Abstrak
Latar Belakang: Pisang merupakan buah tropis yang sudah populer di masyarakat, dan potensial dikembangkan di Indonesia. Terdapat banyak varietas pisang yang tumbuh liar maupun dibudidaya oleh masyarakat. Hal ini menyebabkan adanya perbedaan karakter antar tiap jenisnya. Perbedaan itu dapat dilihat dari penampilan tanaman seperti batang semu, daun, bunga, dan buah. Perbedaan tersebut penting sekali untuk diketahui hubungan kekerabatan antar jenisnya sehingga dapat diperoleh informasi awal dalam memperbaiki sifat genetik yang akan menghasilkan tanaman dengan varietas baru yang lebih unggul.

Metode: Penelitian ini dilakukan pada bulan Desember 2012 sampai Mei 2013 dengan lokasi penelitian Pulau Ambon dan menggunakan metode eksplorasi berdasarkan panduan deskriptor pisang dari International Plant Genetic Resources Institute (IPGRI, 1996).

Hasil: Penelitian menunjukkan bahwa terdapat 7 varietas yang ditemukan dan diidentifikasi yaitu pisang Empat puluh hari, Jawaka, Kepok, Ambon hijau, Raja, Emas dan Tanduk dengan penampilan morfologis yang bervariasi dan terbentuk 2 kluster utama dengan hubungan kekerabatan yang dekat dan jauh.

Kesimpulan: Pisang di pulau Ambon memiliki karakterisasi sehingga banyak sumber potensi keragaman yang perlu diungkap lebih banyak.
\end{abstract}

Kata Kunci: Hubungan kekerabatan, Fenetik, Pisang, Pulau Ambon 


\section{PENDAHULUAN}

Pisang merupakan buah tropis yang sudah populer di masyarakat, dan potensial dikembangkan di Indonesia (Astawan, 2008). Saat ini pisang termasuk komoditas unggulan dan memberikan kontribusi paling besar terhadap produksi buah-buahan nasional. Selain rasanya yang enak, pisang juga mengandung gizi, vitamin, dan kalori, sehingga bermanfaat untuk kesehatan (Prahardini $d k k, 2010)$. Menurut Simmond, (1955), tanaman pisang yang umum dibudidayakan sekarang merupakan keturunan dari Musa acuminata Colla (A) dan Musa balbisiana Colla (B) yang termasuk golongan Eumusa. Pisang-pisang tersebut mempunyai jumlah kromosom yang beragam yaitu 22, 33 dan 44 kromosom dengan kromosom dasar $n=11$. Dengan demikian kultivar tersebut masing-masing bersifat diploid, triploid dan tetraploid. Kultivar yang bersifat triploid mempunyai anggota yang paling banyak, sedangkan yang paling sedikit adalah kultivar tetraploid. Kultivar-kultivar yang banyak terdapat di Indonesia adalah diploid dan triploid. Jenis pisang yang bersifat diploid dengan genotip AA diantaranya adalah pisang Emas, pisang Seribu dan pisang Buaya. Jenis pisang triploid dengan genotip AAA adalah pisang Ambon, pisang Badak; pisang triploid dengan genom $A A B$ adalah pisang Raja, genotip $A B B$ adalah pisang kepok, dan genotip BB yaitu pisang Batu.

Banyaknya kultivar pisang yang ada ini menyebabkan perbedaan karakter antar setiap jenisnya. Perbedaan itu dapat dilihat dari penampilan tanaman seperti batang semu, daun, bunga, dan buah. Dengan perbedaan tersebut penting sekali untuk diketahui hubungan kekerabatan antar jenisnya sehingga dapat diperoleh informasi awal dalam memperbaiki sifat genetik yang akan menghasilkan tanaman dengan varietas baru yang lebih unggul. Beberapa penelitian telah dilakukan dalam menentukan hubungan kekerabatan pada pisang diantaranya adalah penelitian yang dilakukan oleh Jumari dan Pudjoarinto (2000) yang meneliti tentang kekerabatan fenetik kultivar pisang di Jawa. Penelitian lain dilakukan oleh Permana (2011) yang meneliti tentang keanekaragaman dan kekerabatan fenetik tanaman pisang di Kecamatan Mangunjaya Kabupaten Ciamis pada 15 kultivar pisang dengan kekerabatan fenetik terdekat yaitu antara pisang Raja Bulu dan Raja Nangka dengan jarak kekerabatan sebesar 0,095.

Penelitian-penelitian sejenis ini belum sama sekali dilakukan di Pulau Ambon, padahal seperti yang diketahui, Pulau Ambon adalah salah satu sentra produksi pisang. Hal ini dibuktikan dengan melimpahnya buah Pisang di pasaran lokal dengan berbagai jenisnya yang selalu ada setiap saat. Dengan demikian pisang yang ada di pulau Ambon belum terkarakterisasi sehingga banyak sumber potensi keragaman genetik pisang yang belum diketahui. Penelitian ini bertujuan untuk menganalisis hubungan kekerabatan fenetik varietas pisang (Musa sp) di pulau Ambon.

\section{METODE}

Penelitian ini dilakukan pada bulan Desember 2012 sampai Mei 2013 dengan lokasi penelitian yang bertempat di Desa Latuhalat, Mahia, Tulehu, dan Seith kepulauan Ambon yang merupakan representatif dari pulau Ambon yang terdiri dari jazirah Leihitu dan Leitimur. Alat dan bahan yang digunakan dalam penelitian ini adalah peralatan untuk pengamatan morfologis berupa buku lapangan untuk mencatat hasil karakterisasi, roll meter untuk mengukur tinggi batang, penggaris untuk mengukur panjang dan lebar bagian tanaman, kamera digital merk Olympus $\mathrm{x}$ $940 / 2680$ untuk mengambil gambar sampel tanaman. Cara kerja dalam penelitian ini adalah pengamatan karakter morfologis pada 4 lokasi dengan menggunakan metode eksplorasi berdasarkan panduan deskriptor pisang dari International Plant Genetic Resources Institute (IPGRI, 1996) dengan modifikasi berdasarkan keberadaan pisang tersebut. Karakter morfologis yang diamati berupa karakter kualitatif dan kuantitatif. Organ tanaman yang diamati adalah organ vegetatif yang meliputi 10 karakter batang, 18 karakter daun, 10 karakter tangkai daun, dan 21 karakter anakan. Organ generatif terdiri dari 26 karakter bunga, 18 karakter buah dan 3 karakter biji. Karakterisasi dilakukan pada tanaman pisang yang memiliki jantung dan buah yang diperkirakan sudah tua. Setelah itu buah diambil dari pohon dan dibiarkan masak dengan 
sendirinya untuk mendapatkan hasil dari karakter buah dan biji setelah masak. Data morfologis hasil pengamatan ditampilkan dalam data visual yang mewakili penampilan masing-masing organ, dan data skoring morfologis. Selanjutnya hasil skoring distandarisasi sesuai data biner $1 / 0$ dan dianalisis dengan program NTSys-PC versi 2.01. Analisis pengelompokan data morfologis, menggunakan Sequential Agglomerative Hierarchical and Nested (SAHN)-UPGMA (Unweight pair group method arithmetic average) dan disajikan dalam bentuk dendogram.

\section{HASIL DAN PEMBAHASAN}

Berdasarkan penelitian yang telah dilakukan di 4 lokasi di pulau Ambon, terdapat 7 jenis pisang yang ditemukan di keseluruhan lokasi. Inventarisasi jenis-jenis pisang tersebut dapat dilihat pada tabel 1 berikut.

Tabel 1. Penemuan Jenis Pisang Pada Lokasi Penelitian

\begin{tabular}{|c|c|}
\hline Lokasi Penelitian & $\begin{array}{c}\text { Jenis Pisang yang } \\
\text { ditemukan }\end{array}$ \\
\hline 1. Latuhalat & $\begin{array}{ll}\text { - } & \text { Empat puluh hari } \\
\text { - } & \text { Jawaka } \\
\text { - } & \text { Kepok } \\
\text { - } & \text { Raja } \\
\text { - } & \text { Ambon Hijau } \\
\end{array}$ \\
\hline 2. Mahia & $\begin{array}{ll}\text { - } & \text { Empat puluh hari } \\
\text { - } & \text { Jawaka } \\
\text { - } & \text { Kepok } \\
\end{array}$ \\
\hline 3. Tulehu & $\begin{array}{l}\text { - Empat puluh hari } \\
\text { - Jawaka } \\
\text { - Kepok } \\
\text { - Raja }\end{array}$ \\
\hline 4. Seith & $\begin{array}{ll}\text { - } & \text { Empat puluh hari } \\
\text { - Jawaka } \\
\text { - Emas } \\
\text { - Tanduk }\end{array}$ \\
\hline
\end{tabular}

Berdasarkan hasil inventarisasi dilakukan karaterisasi morfologis untuk menganalisis hubungan kekerabatan fenetik. Hasil pengamatan terhadap karakter morfologis baik pada organ vegetatif maupun organ generatif menunjukkan adanya penampilan morfologis yang beragam pada masing-masing jenis pisang di setiap lokasi maupun antar satu jenis pada masing-masing lokasi. Dari 101 karakter morfologis yang diamati hanya terdapat tujuh karakter yang sama sekali tidak menunjukkan adanya variasi atau perbedaan yakni, karakter keoverlapan daun yang semuanya normal, penampakkan bawah daun yang tidak mengkilat, bentuk lebar tepian tangkai daun yang bersayap, bentuk batang yang tidak cekung, braktea yang bergaris, warna daging buah sebelum masak yang berwarna putih, dan tekstur daging buah yang lembut. Ketujuh karakter ini terlihat sama pada semua jenis pisang yang ditemukan. Hal ini disebabkan karena ciri morfologis pisang pada umumnya demikian, dan ciri-ciri ini dapat dikatakan tidak terpengaruh oleh keadaan atau kondisi lingkungan setempat. Sementara karakter yang lain terlihat jelas variasinya mulai dari karakter batang sampai karakter buah.

Pada organ vegetatif, perbedaan karakter morfologis terlihat jelas pada karakter antara lain: pada karakter batang meliputi, tinggi, bentuk, warna utama, pigmentasi, dan bercak pada batang. Pada karakter daun meliputi, ketegakkan daun, panjang helaian, lebar helaian, warna permukaan atas daun, simetris pangkal daun, bentuk pangkal daun, warna tulang 
atas, warna tulang bawah, dan warna tepi pangkal daun. Ketegakkan daun dengan tipe tegak menurut Kusumawati dan Syukriani (2008), intensitas cahaya yang diterima sangat kecil karena luasan daun yang diterpa cahaya tidak ke seluruh permukaan daun. Sedangkan ketegakkan daun tipe merunduk, dikatakan lebih menguntungkan jika dilihat dari segi penerimaan cahaya, karena luasan daun yang diterpa cahaya lebih besar sehingga intensitas cahaya yang diterima juga lebih banyak. Hal ini akan berpengaruh terhadap laju proses fotosintesis yang nantinya juga akan berpengaruh terhadap pertumbuhan dan perkembangan tanaman.

Perbedaan karakter tangkai daun terletak pada, bentuk dan warna bercak, bentuk kanal, warna tepi tepian tangkai daun, panjang dan warna tangkai. Pada Karakter anakan meliputi, warna tepi daun, warna tulang atas dan bawah daun, bentuk pangkal daun, warna tangkai daun, warna tepi tangkai daun, tingkat perkembangan anakan, dan posisi anakan. Variasi pada posisi anakan menurut Sudarnadi (1996) dipengaruhi oleh kuncup-kuncup tunas dan akar liar yang tumbuh menyebar secara lateral yang dapat mencapai 4-5 meter. Oleh sebab itu ada posisi anakan yang rapat dengan induknya, agak jauh dari induknya, dan yang menjauh dari induknya.

Pada organ generatif perbedaan karakter morfologis terlihat jelas pada karakter bunga yang meliputi, panjang dan lebar tangkai, buku kosong pada tangkai, posisi dan penampakkan tandan, bentuk pangkal dan ujung braktea, warna dasar dan lobus tenda bunga, warna dan bentuk tangkai putik. Pada karakter buah meliputi, jumlah, panjang, dan bentuk ujung buah, panjang dan lebar tangkai, warna kulit setelah masak, tebal kulit, warna daging pada waktu masak, dan rasa. Sudarnadi (1996) menjelaskan variasi karakter buah yang terdapat pada jenis pisang sebagai berikut: Pisang kelompok AAA (pisang Ambon Hijau), buahnya sedang sampai besar dengan kulit tebal berwarna hijau kekuningan, daging buahnya manis berwarna putih, teksturnya baik, manis dan harum. Pisang Kelompok AA (pisang Emas dan Empat puluh hari), buah kecil dengan kulit tipis, berwarna kuning keemasan. Daging buahnya agak lunak, agak berlendir, berwarna kuning sampai oranye muda, rasanya sangat manis. Pisang Kelompok AAB (Pisang Raja), buah besar dengan kulit tebal dan kasar, kuning sampai oranye, daging buah putih sampai kuning, wangi dan manis. Pisang Kelompok AAB (Pisang Tanduk), buahnya besar dan panjang, warna kulitnya kuning kecoklatan atau coklat, daging buahnya agak berlendir berwarna kuning atau oranye, manis dan setiap tandan hanya ada dua sisir. Pisang Kelompok ABB (Pisang Kepok dan Jawaka), buah sedang sampai besar, kulitnya tebal dan kasar, berwarna kuning kecoklatan, daging buahnya manis, harum dan mengandung pati. Penjelasan ini sesuai dengan hasil karakterisasi yang ditemukan di lapangan.

Adanya berbagai variasi atau perbedaan terhadap masing-masing karakter yang dimiliki oleh setiap jenis pisang ini dipengaruhi oleh banyak faktor baik faktor lingkungan, genetis maupun faktor bias pada saat melakukan pengamatan di lapangan (Karuwal, 2011). Empat lokasi yang menjadi lokasi pengamatan memiliki kondisi lingkungan yang berbeda seperti $\mathrm{pH}$ tanah, ketinggian tempat dan kelembapan sehingga menyebabkan sifat adaptif yang berbeda. Desa Latuhalat merupakan dataran rendah, Dusun Mahia merupakan dataran tinggi, dan Desa Tulehu dan Seith merupakan dataran sedang. Faktor lain yang juga memepengaruhi misalnya variasi warna, menurut Tjitrosoepomo (2010), warna suatu jenis tumbuhan dapat berubah menurut keadaan tempat tumbuhnya dan erat sekali hubungannya dengan persediaan makanan serta penyinaran. Kemudian variasi ukuran dan jumlah buah menurut Hakim (1986) dalam Kusumawati dan Syukriani (2008) menjelaskan, kesuburan tanah merupakan faktor utama yang mempengaruhi pertumbuhan dan produksi tanaman. Ketersediaan unsur hara dalam jumlah yang cukup akan sangat menentukan dalam peningkatan ukuran buah karena pada saat pertumbuhan buah daya saing untuk pengambilan asimilat semakin besar.

\section{Hubungan Kekerabatan Fenetik Jenis Pisang di Pulau Ambon}

Untuk mengetahui hubungan kekerabatan fenetik jenis pisang, maka dianalisis kesamaan (similarity) antar jenis 
pisang tersebut berdasarkan karakter morfologisnya dengan menggunakan program NTsys yang dapat dilihat pada tabel 2.

Tabel 2. Nilai Indeks Similaitas Jenis Pisang berdasarkan Karakter Morfologis

\begin{tabular}{|c|c|c|c|c|c|c|c|c|c|c|c|c|c|c|c|c|}
\hline Rowicols & III & EH2 & 853 & EH4 & 7.h! & $\pi / 2$ & Jnas & Jnt & $x=1$ & $x 22$ & 103 & 201 & $2 \sqrt{2}$ & AII & NS & סות \\
\hline 85i & 1 & & & & & & & & & & & & & & & \\
\hline 852 & 0.643564 & 1 & & & & & & & & & & & & & & \\
\hline SEB & 0.683168 & 0.643564 & 1 & & & & & & & & & & & & & \\
\hline SE4 & 0.630363 & 0.630363 & 0.632363 & 1 & & & & & & & & & & & & \\
\hline $\mathrm{m} 1$ & 0.568647 & 0.566647 & 0.568647 & 0.568647 & 1 & & & & & & & & & & & \\
\hline $3 \pi 2$ & 0.568647 & 0.568647 & 0.564647 & 0.560647 & 0.639064 & 1 & & & & & & & & & & \\
\hline 513 & 0.568647 & 0.568647 & 0.568647 & 0.568647 & 0.680968 & 0.638664 & 1 & & & & & & & & & \\
\hline Jin & 0.568647 & 0.568647 & 0.568647 & 0.568547 & 0.747525 & 0.638064 & 0.680968 & 1 & & & & & & & & \\
\hline $\mathrm{k} 91$ & 0.568647 & 0.568647 & 0.568647 & 0.568647 & 0.792079 & 0.638064 & 0.60096 & & 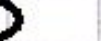 & & & & & & & \\
\hline 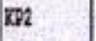 & 0.568667 & 0.568647 & $0.568647 ?$ & $0.568647 ?$ & 0.688064 & 0.792079 & 0.638064 & 0.638064 & 0.638064 & 1 & & & & & & \\
\hline $\mathbb{B} 3$ & 0.568647 & 0.568647 & 0.568647 & 0.568647 & 0.633064 & $0.68 B 119$ & 0.638064 & 0.638064 & 0.638064 & 0.688119 & 1 & & & & & \\
\hline $3 N 1$ & 0.568647 & 0.5686477 & 0.568647 & 0.568647 & 0.630968 & 0.638064 & 0.727723 & 0.680968 & 0.680968 & 0.638064 & 0.638064 & 1 & & & & \\
\hline $8 \sqrt{2}$ & 0.568647 & 0.568647 & 0.568647 & 0.568647 & 0.680968 & 0.638064 & 0.792079 & 0.680968 & 0.680968 & 0.638064 & 0.638064 & 0.727723 & 1 & & & \\
\hline II & 0.630363 & 0.630363 & 0.630363 & 0.702970 & 0.569647 & 0.568647 & 0.668647 & 0.566647 & 0.568647 & 0.568647 & 0.568647 & 0.568647 & 0.569647 & 1 & & \\
\hline as & 0.596040 & 0.596040 & 0.596040 & 0.596040 & 0.568647 & 0.562647 & 0.568647 & 0.568647 & 0.568647 & 0.568647 & 0.568647 & 0.568647 & 0.568647 & 0.596040 & 1 & \\
\hline סוב & 0.559647 & 0.559647 & 0.5596447 & 0.559647 & 0.621562 & 0.621562 & 0.621562 & 0.621562 & 0.621562 & 0.621562 & 0.621562 & 0.621562 & 0.621562 & 0.559647 & & \\
\hline
\end{tabular}

Keterangan: EH1: Empat puluh hari Latuhalat. EH2: Empat puluh hari Mahia. EH3: Empat puluh hari Tulehu. EH4: Empat puluh hari Seith. JW1: Jawaka Latuhalat. JW2: Jawaka Mahia. JW3: Jawaka Tulehu. JW4: Jawaka Seith. KP1: Kepok Latuhalat. KP2: Kepok Mahia. KP3: Kepok Tulehu. R1: Raja Latuhalat. R2: Raja Tulehu. AH: Ambon Hijau Latuhalat. EMS: Emas Seith. TND: Tanduk Seith.

Dari tabel 2 dapat dilihat bahwa nilai koefisien similaritas karakter morfologis antar jenis pisang menunjukkan rentang nilai berkisar antara 0,55-0,74. Nilai koefisien similaritas tertinggi ditemukan pada pisang Jawaka lokasi Seith dengan pisang Kepok lokasi Latuhalat dengan nilai 0,747525 sedangkan nilai koefisien terendah ditemukan antara pisang Emas dan Pisang Tanduk dengan nilai 0,559647.

Selanjutnya berdasarkan nilai similaritas dibuat dendogram yang dapat mengelompokkan seluruh data karakter morfologis antar jenis pisang yang dapat dilihat pada gambar 1 . 


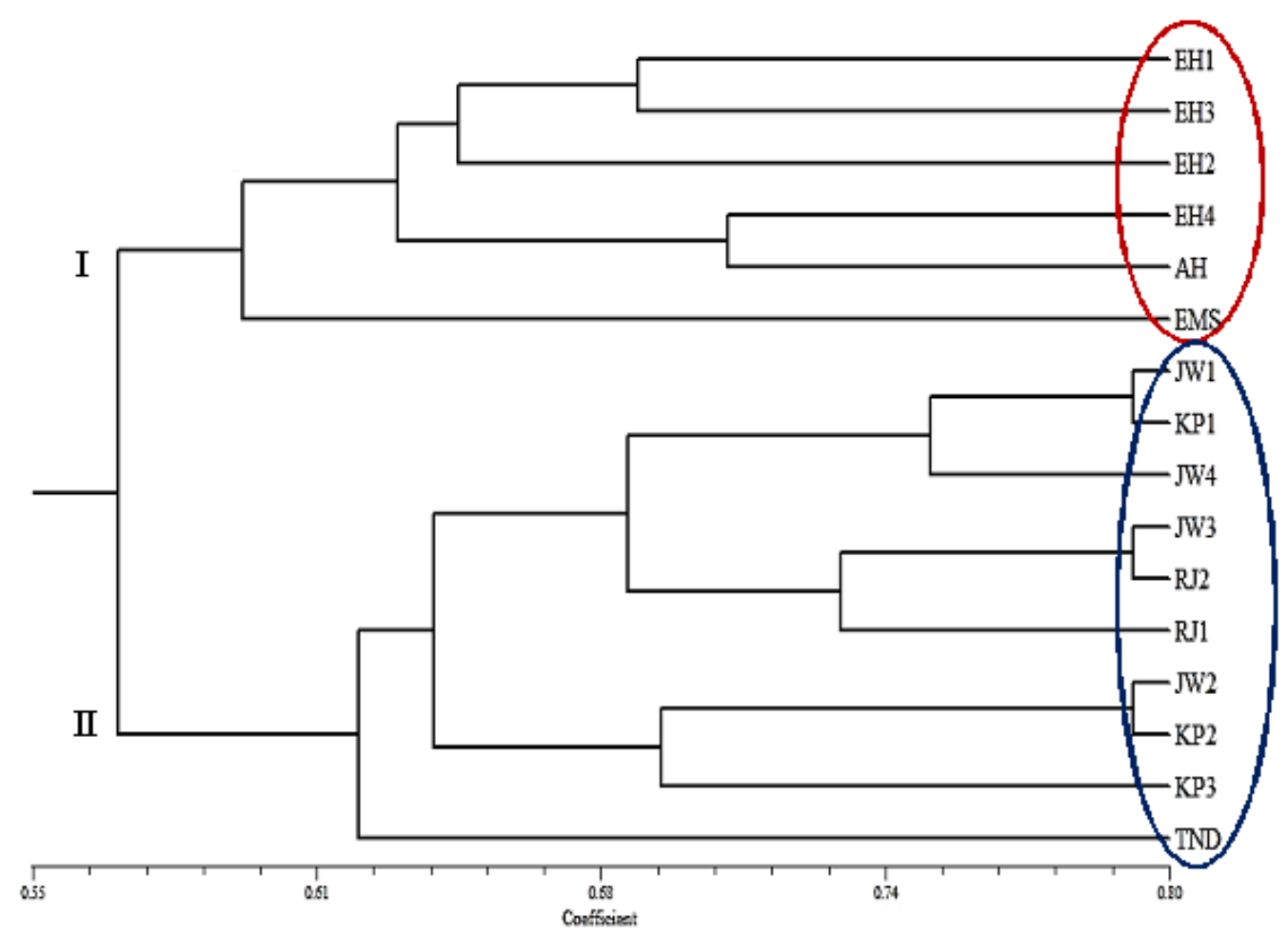

Gambar 1. Dendogram Jenis Pisang Berdasarkan Karakter Morfolgis

Dari dendogram yang terlihat pada gambar 1 menunjukkan ke-16 tanaman pisang yang terdiri atas tujuh jenis ini terbagi dalam dua kelompok besar dengan nilai koefisien tingkat kesamaan berkisar antara $0,55-0,80$.

Kelompok I terdiri atas pisang Empat puluh hari dari semua lokasi, pisang Ambon Hijau, dan pisang Emas. Kelompok II terdiri atas pisang Jawaka dari semua lokasi, Kepok dari lokasi Latuhalat, Mahia, dan Tulehu, Raja dari lokasi Latuhalat dan Tulehu, dan pisang tanduk yang hanya ditemukan di lokasi Seith.

Analisis NTSys versi 2.0 terhadap ke-16 tanaman pisang yang termasuk dalam tujuh jenis berdasarkan 101 karakter morfologis di 4 lokasi menghasilkan dendogram dengan nilai koefisien similaritas berkisar antara 0,55-0,80 dan terdiri atas dua kelompok utama. Dendogram yang dihasilkan menunjukkan tiap kelompok terdiri atas genom yang berbeda. Menurut Sudarnadi (1996) jenis pisang yang terdapat dalam kelomok I terdiri atas jenis pisang dengan genom AA dan AAA, sedangkan kelompok II terdiri atas jenis pisang dengan genom $A A B$ dan ABB.

Menurut penelitian yang dilakukan oleh Robiah (2004) terhadap 27 aksesi pisang berdasarkan penanda fenotipik menunjukkan dendogram dengan nilai koefisien similaritas pada kisaran 0,31-0,94 dan terdiri atas 4 kelompok aksesi utama dan tiap kelompok mewakili genom yang berbeda. Penelitian oleh Karuwal (2011) menunjukkan dendogram dengan nilai koefisien similaritas berkisar antara 0,640,92 dan terdiri atas 2 kelompok utama dimana lokasi yang letaknya berdekatan mengelompok dalam satu kelompok yang sama. Perbedaan nilai koefisien similaritas dan banyaknya kelompok dalam dendogram tersebut dipengaruhi oleh jenis pisang dan jumlah karakter morfologis yang digunakan pada saat observasi.

Berdasarkan nilai indeks similaritas (tabel 2.) dan dendogram yang ditampilkan (gambar 1.), hubungan kekerabatan fenetik terdekat ditemukan pada jenis pisang Kepok lokasi Latuhalat dan Jawaka lokasi Seith yang menurut Sudarnadi (1996) keduanya memiliki genom AAB dengan indeks similiritasnya sebesar 0,747525 . Hubungan kekerabatan fenetik terjauh ditemukan pada jenis pisang Emas dan pisang Tanduk, yang menurut Sudarnadi (1996) pisang Emas bergenom $A A$ dan pisang Tanduk bergenom ABB dengan indeks similaritasnya sebesar 0,559647 . 
Jumari dan Pudjoarinto (2000) dalam penelitiannya yang menggunakan 125 kultivar pisang dari 22 daerah di pulau Jawa menemukan hubungan kekerabatan yang paling jauh dimiliki oleh jenis pisang Raja Seribu dengan jarak taksonomi 4,068. Sedangkan pisang Becici dan Emas mempunyai kekerabatan paling dekat dengan jarak taksonomi 1,620. Sementara hasil penelitian oleh Permana (2011) dengan 15 kultivar pisang di Kecamatan Mangun Jaya menemukan hubungan kekerabatan terdekat terdapat pada pisang Raja bulu dan Raja nangka dengan jarak taksonomi sebesar 0,0956.

\section{SIMPULAN}

1. Berdasarkan hasil pengamatan, jenis pisang yang ditemukan dan telah diinventarisasi serta diidentifikasi berjumlah tujuh jenis pisang yaitu pisang Empat puluh hari, Jawaka, Kepok, Ambon hijau, Raja, Emas dan Tanduk.

2. Berdasarkan hasil karakterisasi morfologis, terdapat variasi penampilan pada setiap jenis pisang di pulau Ambon. Perbedaan terlihat pada bentuk, ukuran, warna, penampakkan tiap organ baik pada batang, daun, bunga dan buah.

3. Berdasarkan indeks similaritasnya, hubungan kekerabatan terdekat yaitu antara pisang Jawaka lokasi Seith dan Kepok lokasi Latuhalat dengan nilai similaritas sebesar 0,747525 . Sedangkan hubungan kekerabatan terjauh antara pisang Emas dan pisang Tanduk dengan nilai similaritas sebesar 0,559647 .

\section{DAFTAR PUSTAKA}

Astawan, M. 2008. Pisang Buah Kehidupan. $\mathrm{http} / /$ : www.kompas.com.

International Plant Genetic Resources Institute (IPGRI). 1996. Descriptors for
Banana (Musa spp.). International Plant Genetic Resources Institute. Rome:Italy Jumari, A. Pudjiarinto. 2000. "Kekerabatan Fenetik Kultivar Pisang Di Jawa”. Jurnal: Berkala IImiah Biologi 2000, II(9). (Online) http://ilib.ugm.ac.id/jurnal/detail.php?datald=3 30 (diakses tanggal 3 Oktober 2012).

Karuwal, R.L. 2011. Variasi Genetik Pisang Tongkat Langit (Musa troglodytarum L) Berdasarkan Karakter Morfologis dan Molekular. Tesis tidak Diterbitkan. Yogyakarta. Fakultas Biologi Universitas Gajah Mada.

Kusumawati Aries dan Syukriani Lili, 2008. "Identifikasi Karakterisasi Morfologi Genotipe Pisang (Musa Paradisiaca) di Kabupaten Agam Propinsi Sumatera Barat" Jurnal: Jerami, Vol No.2 (online)

Permana FE. 2011. "Keanekaragaman dan Kekerabatan Fenetik Tanaman Pisang (Musa sp.) Di Kecamatan Mangunjaya Kabupaten Ciamis" (Online) http://bio.unsoed.ac.id/367-

keanekaragaman-kekerabatan-fenetiktanaman-pisang-musa-spp-di-

kecamatan-mangunjaya-kabupaten.

(diakses tanggal 3 Oktober 2012)

Prahardini, Yuniarti, dan Krismawati. 2010. "Karakterisasi Varietas Unggul Pisang Mas Kirana dan Agung Semeru di Kabupaten Lumajang". Buletin Plasma Nutfah Vol 16 No.2 (online).

Robi'ah, H. R. 2004. Analisis Keanekaragaman Genetik Pisang Introduksi (Musa spp.) Berdasarkan Penanda Fenotipik dengan Penanda RAPD (Random Amplified Polymorhic $D N A)$. Tesis. IPB: Bogor.

Simmonds, N. W and K. Shepherd. 1955. Bananas. Longmans:London.

Sudarnadi, H. (1996). Tumbuhan Monokotil. PT. Penebar Swadaya. Jakarta. 